\title{
Genetics and molecular epidemiology of multiple myeloma: The rationale for the IMMEnSE consortium (Review)
}

\author{
ALESSANDRO MARTINO $^{1 *}$, JUAN SAINZ ${ }^{2,3 *}$, GABRIELE BUDA $^{4 *}$, KRZYSZTOF JAMROZIAK $^{5}$, \\ RUI MANUEL REIS ${ }^{6,12}$, RAMÓN GARCÍA-SANZ ${ }^{7}$, MANUEL JURADO ${ }^{2,3}$, RAFAEL RÍOS ${ }^{2,3}$, \\ ZOFIA SZEMRAJ-ROGUCKA ${ }^{5}$, HERLANDER MARQUES ${ }^{6}$, FABIENNE LESUEUR $^{8}$, VICTOR MORENO $^{9}$, \\ ENRICO ORCIUOLO ${ }^{4}$, FEDERICA GEMIGNANI $^{10}$, STEFANO LANDI $^{10}$, ANNA MARIA ROSSI $^{10}$, \\ CHARLES DUMONTET $^{11}$, MARIO PETRINI ${ }^{4}$, DANIELE CAMPA ${ }^{1}$ and FEDERICO CANZIAN ${ }^{1}$
}

${ }^{1}$ Genomic Epidemiology Group, German Cancer Research Center (DKFZ), D-69120 Heidelberg, Germany; ${ }^{2}$ Genomic Oncology Area, Pfizer-University of Granada-Andalusian Government Centre for Genomics and Oncological Research (GENYO), 18007 Granada; ${ }^{3}$ Department of Hematology, Virgen de las Nieves University Hospital, 18014 Granada, Spain; ${ }^{4}$ Department of Oncology, Transplants and Advanced Technologies, Section of Hematology, University of Pisa, I-56100 Pisa, Italy; ${ }^{5}$ Department of Hematology, Medical University of Lodz, 93-513 Lodz, Poland; ${ }^{6}$ Life and Health Sciences Research Institute (ICVS), School of Health Sciences, University of Minho, 4710 Braga, Portugal; ${ }^{7}$ University Hospital of Salamanca, Universidad de Salamanca-Centro de Investigación del Cáncer, 37007 Salamanca, Spain; ${ }^{8}$ Genetic Cancer Susceptibility

Group, International Agency for Research on Cancer (IARC), 69372 Lyon, France; ${ }^{9}$ IDIBELL-Catalan Institute of Oncology, CIBERESP and University of Barcelona, Barcelona 08907, Spain; ${ }^{10}$ Department of Biology, Section of Genetics, University of Pisa, I-56126 Pisa, Italy; ${ }^{11}$ INSERM UMR 1052/CNRS 5286, Laboratoire de Cytologie Analytique, Faculté de Medecine Rockefeller, Université Claude Bernard Lyon I, Lyon, France;

${ }^{12}$ Molecular Oncology Research Center, Barretos Cancer Hospital, Barretos, Brazil

Received August 29, 2011; Accepted October 13, 2011

DOI: $10.3892 /$ ijo.2011.1284

\begin{abstract}
There is strong evidence suggesting the presence of a genetic component in the aetiology of multiple myeloma (MM). However no genetic risk factors have been unequivocally established so far. To further our understanding of the genetic determinants of MM risk, a promising strategy is to collect a large set of patients in a consortium, as successfully done for other cancers. In this article, we review the main findings in the genetic susceptibility and pharmacogenetics of MM and present the strategy of the IMMEnSE (International Multiple Myeloma rESEarch) consortium in contributing to determine the role of genetic variation in pharmacogenetics and in MM risk.
\end{abstract}

\section{Contents}

1. Introduction: multiple myeloma

Correspondence to: Dr Alessandro Martino, German Cancer Research Center (DKFZ), Genomic Epidemiology Group, Im Neuenheimer Feld 580, D-69120 Heidelberg, Germany

E-mail: a.martino@dkfz-heidelberg.de

*Contributed equally

Key words: IMMEnSE consortium, multiple myeloma, SNPs, genetic susceptibility, pharmacogenetics
2. Lifestyle, environmental and occupational-related risk factors in multiple myeloma

3. Genetic risk factors in multiple myeloma

4. Pharmacogenetics of multiple myeloma

5. Limits and perspectives: the rationale for the IMMEnSE consortium

6. Future directions

\section{Introduction: multiple myeloma}

Multiple myeloma (MM) is a malignancy of plasma cells usually infiltrating the bone marrow, associated with the production of a monoclonal immunoglobulin ( $\mathrm{M}$ protein) which can be detected in the blood and/or urine (1). The uncontrolled growth of myeloma cells has many consequences, including skeletal destruction, bone marrow failure, suppression of normal immunoglobulin production and renal insufficiency (2).

MM arises worldwide at an age-standardized (ASR) rate of 1.5 new cases every 100,000 people per year and is responsible of an ASR of mortality of 1 in 100,000 subjects per year. In Europe the ASR incidence is 2.9 new cases every 100,000 people, ranging from 4.2 in Luxembourg to 0.9 in Moldova, and is about 1.5-fold higher in males $(\mathrm{ASR}=2.9)$ than in females $(\mathrm{ASR}=2.0)(3-5)$. The highest annual incidence of MM has been found in African Americans followed either by Europeans or American Caucasians and Asians who present the lowest incidence even when they live in Western societies (6-11). The 
overall incidence rates range from a high of 13.1/100,000 per year for black males to 2.9/100,000 per year for white females $(8,11)$. MM is common in the elderly, with incidence rates increasing with age, it occurs rarely before 40 years (12) and presents an extremely low frequency in young people $(9,13,14)$. It has been shown that MM could evolve from an asymptomatic premalignant condition termed monoclonal gammopathy of undetermined significance (MGUS) $(15,16)$. The frequency of MGUS is over 3\% in the population above the age of 50 years and over $5 \%$ in persons aged 70 years or older $(17,18)$. This condition seems to be related to progression to $\mathrm{MM}$ or other plasma cell disorders at a steady rate of $1.5 \%$ per year, and after $>25$ years of observation about $15-17 \%$ of MGUS subjects develop MM (19). In some patients, an intermediate asymptomatic, but more advanced premalignant stage, defined as smouldering multiple myeloma (SMM) could be clinically recognized (20).

MM diagnosis requires $10 \%$ or more clonal plasma cells on bone marrow examination or a biopsy proven plasmacytoma and evidence of end-organ damage such as hypercalcemia, renal insufficiency, anaemia or bone lesions, defined as CRAB (calcium elevation, renal insufficiency, anaemia and bone lesions criteria) that can be related to the underlying plasma cell disorder $(1,21)$.

Symptomatic (active) disease should be treated immediately, whereas asymptomatic myeloma requires only clinical observation, since early treatment with conventional chemotherapy has shown no benefit. The aim of the therapy is represented by the achievement of the best possible response: complete response (CR) or very good partial response (VGPR) (22-24). The level of response, and in particular achievement of CR, seems to be associated with an improved long-term outcome. Overall survival (OS) in myeloma has improved significantly in the last decade with the emergence of thalidomide (25), bortezomib (26) and lenalidomide (27). Bortezomib is a firstin-class proteasome inhibitor (28); the complete mechanism of action of thalidomide and lenalidomide is still unclear but both of them are immune-modulatory drugs (29). Treatment strategies include the use of therapy with thalidomide, lenalidomide or bortezomib plus hematopoietic autologous stem-cell transplantation (ASCT) for patients under the age of 65 years, who do not have substantial heart, lung, renal or liver dysfunction. Alternatively, the use of combination therapy including steroids and/or alkylating agents together with one or two of the new drugs (thalidomide, bortezomib and lenalidomide) is more appropriate for elderly patients or those with severe co-morbidities. The role of maintaining therapy is still a matter of debate (30).

\section{Lifestyle, environmental and occupational-related risk factors in multiple myeloma}

MM risk is clearly related to age (31), gender, ethnicity (11) and the presence of pre-malignant conditions such as MGUS (17). Additional factors have been suggested to have an effect on the risk of developing MM. There is epidemiological evidence supporting an increased risk of MM among obese people and for those who have a low intake either of fish or vegetables (32-36). A number of cohort and case-control studies have also described a positive relationship between MM and patients either with autoimmune diseases $(37,38)$ or viral infections (39-41). Many other studies have investigated the relationship between exposure to toxins and increased risk of MM, with controversial results (42-46). While some studies have shown that exposures to pesticides (47-49), organic solvents (50), hairdresser's products (51), rubber (52) are associated with an increased risk of MM, other studies have not found a significant relationship (48,53-55). Researchers have also examined whether smoking (56), alcohol consumption (57) or ionizing radiation exposures (58) affected the risk of MM but, again, obtained data were largely inconsistent (59-61).

\section{Genetic risk factors in multiple myeloma}

Converging evidence of MM in monozygotic twins (62) and familial aggregation of MM (63-69) strongly suggest that MM aetiology has a robust genetic component. For many other types of tumors, association studies, including Genome-Wide Association Studies (GWAS), have shown that genetic risk is influenced by the effect of the co-inherited common genetic low-penetrance variants. Single Nucleotide Polymorphisms (SNPs) are the major source of genetic variation in humans and thought to be responsible, at least in part, for the individual differences in genetic susceptibility to complex diseases as tumors. This is likely to be the case for MM as well. Several genes belonging to different pathways have been associated with MM risk, although the results were controversial. Table I summarizes the positive associations reported in the literature between genetic variants and MM susceptibility in candidate gene studies. Up to date, a GWAS on MM risk is still lacking.

Polymorphisms in cytokine genes. The first study on SNPs in MM genetic susceptibility was reported in 2000 by Zheng et $a l$ and investigated the role of 3 SNPs, respectively, in TNF- $\alpha$ (-308G/A, rs1800629), IL6 (-174G/C, rs1800795) and ILIB $(+3954 \mathrm{~T} / \mathrm{C}$, rs1143634) genes as well as a VNTR polymorphism in the $I L I R N$ gene. In this study, no evidence of association between any of the studied genetic variants and MM risk was reported (70).

In general, cytokine-encoding genes have been extensively investigated (70-86), due to the high degree of polymorphisms characterized in these genes and to their important role in the bone marrow microenvironment and B-cell development.

One of the most investigated genetic loci in MM risk is the -308G/A SNP (rs1800629) which belongs to the $T N F-\alpha$ gene. While no association between MM risk and SNP -308G/A (rs1800629) of TNF- $\alpha$ gene was found in a previous study (70), Davies and colleagues showed a significantly higher percentage of heterozygous individuals for both $T N F-\alpha-308 \mathrm{G} / \mathrm{A}$ SNP and $L T-\alpha+252 \mathrm{~A} / \mathrm{G}$ (rs909253) SNP among MM cases in respect to controls, suggesting that the higher $T N F-\alpha$ producers had a 2-fold higher risk to develop MM (78). In a subsequent study, Morgan et al failed to confirm the association between $T N F-\alpha$ $-308 \mathrm{G} / \mathrm{A}$ and $L T-\alpha+252 \mathrm{~A} / \mathrm{G}$ haplotype and MM risk, evidencing on the other hand an association between the TNF- $\alpha-308 \mathrm{~A}$ allele and a decreased risk to develop MM (79). The association of the TNF- $\alpha-308 \mathrm{~A}$ allele with a reduced risk to develop MM has been confirmed by two recent studies $(73,83)$.

Investigations of SNPs in genes belonging to the IL6 pathway are intriguing since IL6 and IL6-mediated signaling are thought 


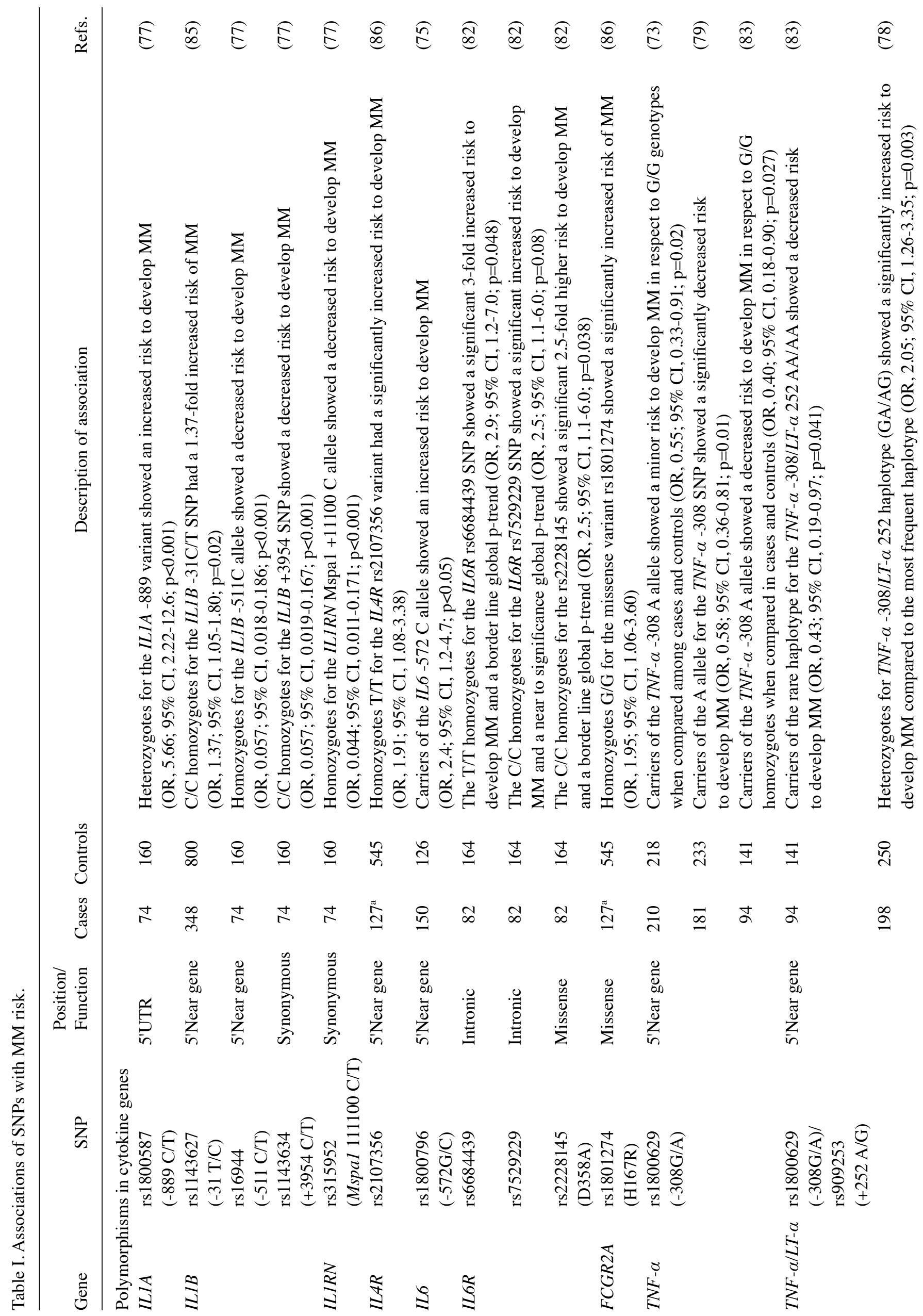




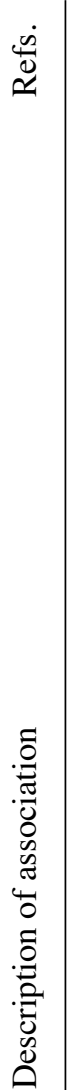

要

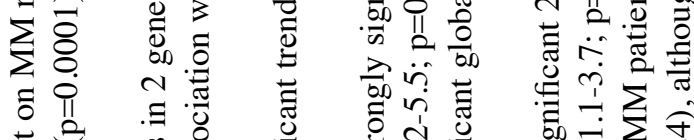

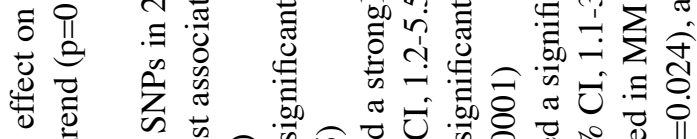

势

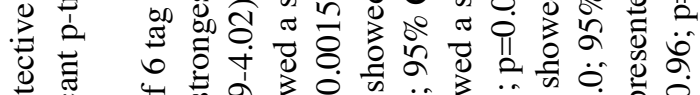

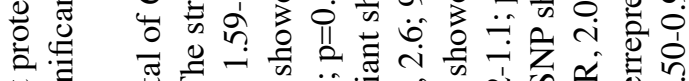

- चू है

क

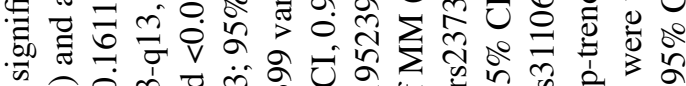

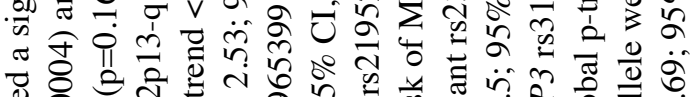

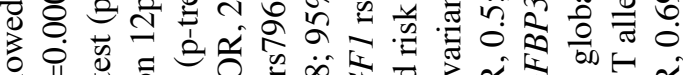

क्रा

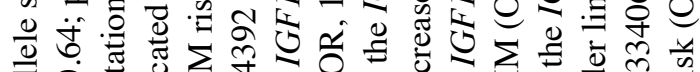

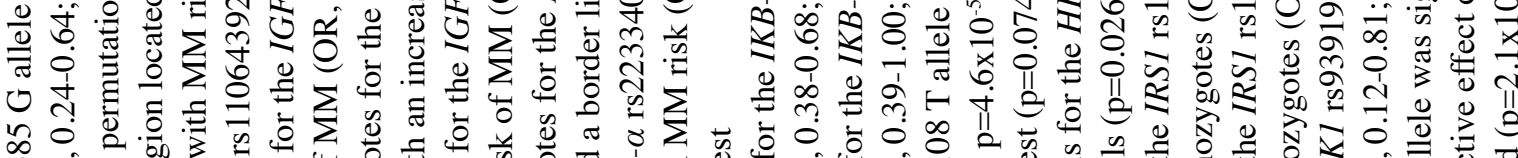

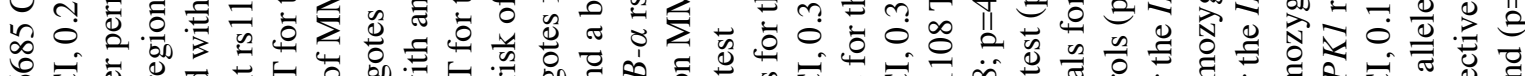

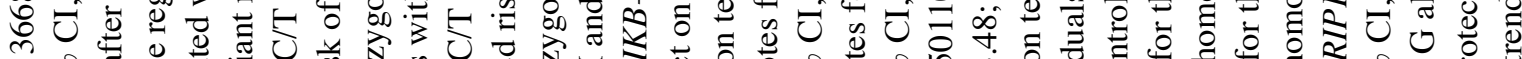

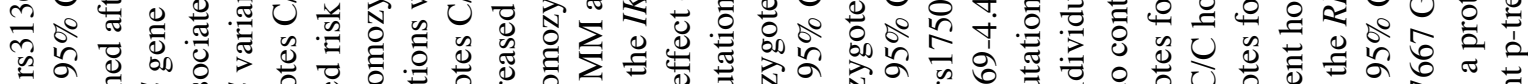
人ô.

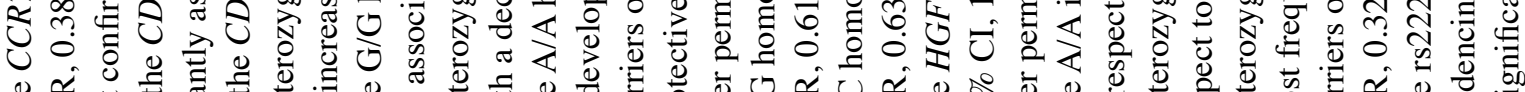

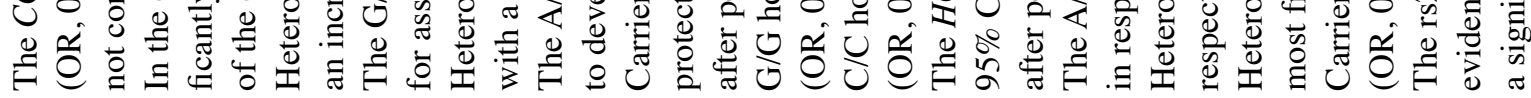

总

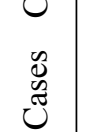

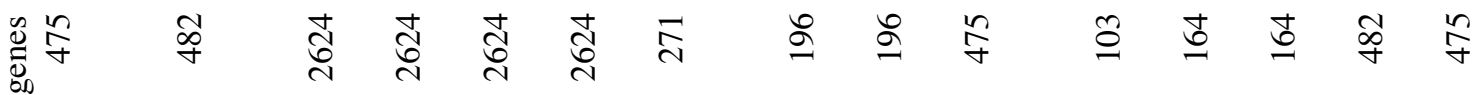

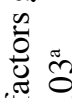
$=$

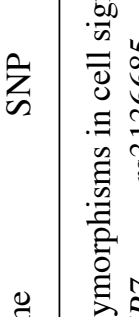

जัए

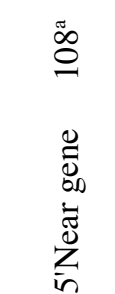<smiles>C1CCC2(CC1)CCCC2</smiles>

$\infty$

离

$\infty$

$\infty$

ถุ

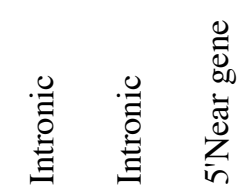

党

in

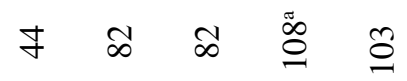

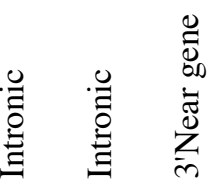<smiles>C1CCC1</smiles>
䓂总高

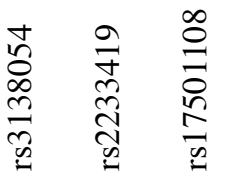

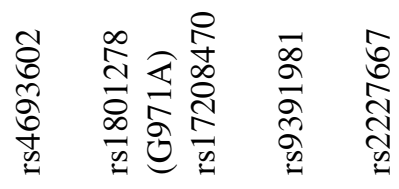

¿ิ

应竞 


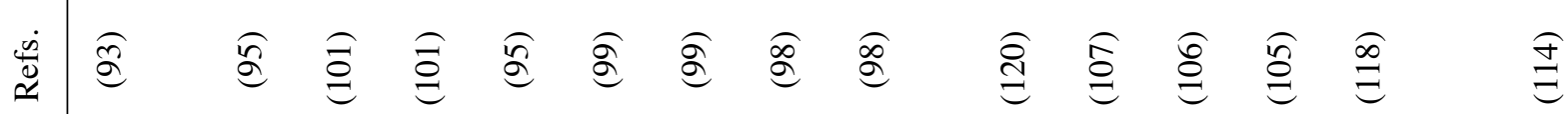

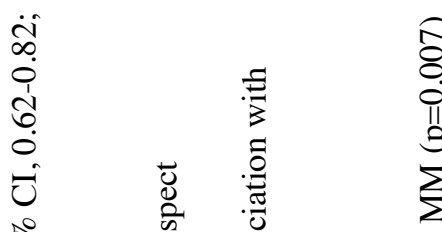

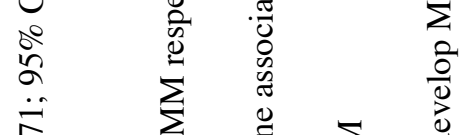<smiles>[Li][13CH3]</smiles>

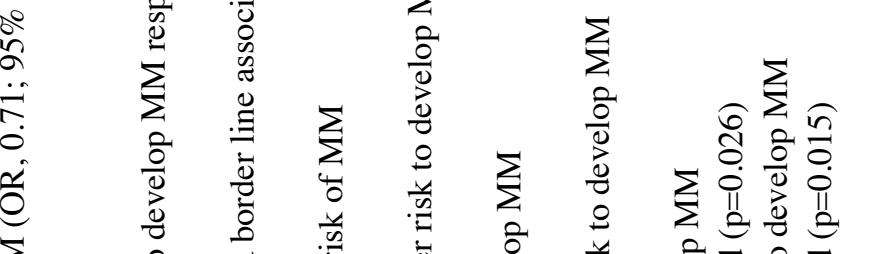

$\sum \quad \begin{array}{lll}0 & \pi & 0 \\ & 0 & 0\end{array}$

离施

.

药

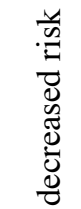

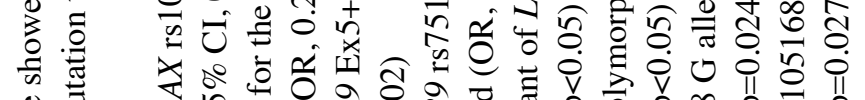

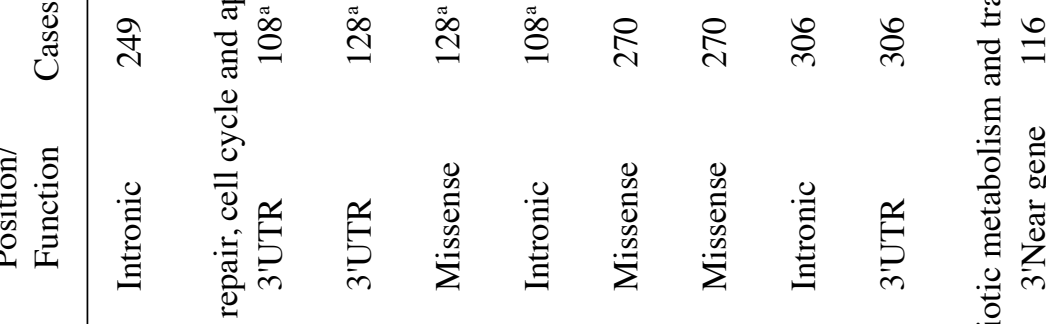
:

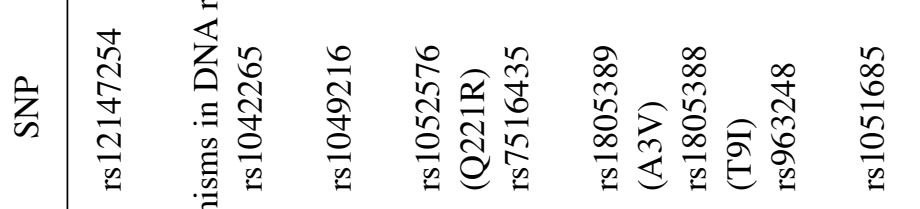

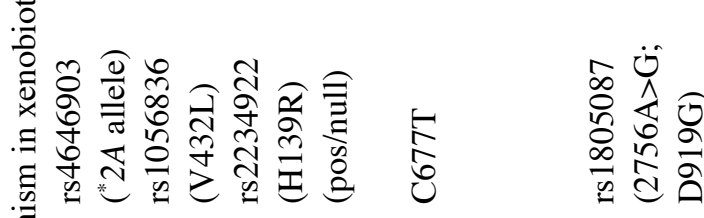

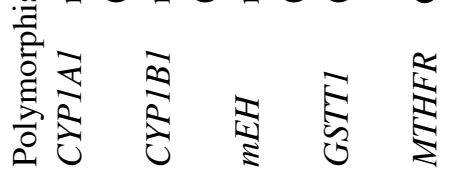


to be relevant players in MM pathogenesis (87). Several reports investigated SNPs in IL6, IL6R and IL6ST genes (75,76,80-82) and up to date, several studies failed to evidence association with the well studied IL6 promoter -174G/C SNP (rs1800795) (70,75,80-82). In one study the IL6 -572G/C (rs1800796) was associated with an increased risk to develop MM for carriers of the $-572 \mathrm{C}$ allele (75). However, this association was not confirmed in a following study (82), whereas an increased risk of MM was found for carriers of the minor allele of SNPs D398A (rs8192284), rs7529229 and rs6684439 in the IL6R gene. Nevertheless, association within IL6R SNP rs8192284 was investigated in a third study that did not confirm the previous findings (81). Several SNPs in other cytokines and immunity-related genes, such as $I L 1 B, I L 1 A, \operatorname{ILIRN}(77,85)$, $I L 4 R$ and FCGR2A (86) have been found to be associated with MM risk, although there is a lack of replication studies limiting the applicability of these findings.

Polymorphisms in growth factors and cell signaling genes. The complex network of signaling pathways activated by several proteins present in the bone marrow microenvironment play a relevant role in malignant plasma cells proliferation, migration and survival (88). The activation of the nuclear transcription factor $N F-\kappa B$ is thought to be one of the most important factors to enhance cell proliferation in MM pathogenesis $(89,90)$. The minor alleles of SNPs in genes related to the $N F-\kappa B$ pathway, such as the inhibitor $I \kappa B \alpha(\mathrm{rs} 2233406, \mathrm{rs} 3138054, \mathrm{rs} 2233419)$ and the transcriptional activator TRAF3 (rs12147254) have been associated with a protective effect on MM development (91-93).

Several polymorphisms in genes related to insulin metabolism resulted associated with MM risk. In particular, three SNPs in the $I G F 1$ gene (rs7965399, rs2195239, rs2373722), one in the IGFBP3 (rs3110697) gene and two in the IRS1 gene have been associated both with increased or decreased risk of MM (82).

Several SNPs in other immunity-related and adhesion/ growth genes, such as SERPINE I, CCR7, HGF, JAK3 (94), CD4 (71), RIPK1 (95) and HPSE (96) have been found to be associated with MM risk. Nevertheless, these results wait to be replicated in independent populations. Other reports did not evidence significant results (97).

Polymorphisms in DNA repair, cell cycle and apoptosis genes. SNPs in genes of the DNA repair system have been deeply investigated to uncover the genetic susceptibility of many cancer types, including MM (98-100). The observation of recurring translocation in MM patients involving the $14 \mathrm{q} 32.3$ cytogenetic band, which is considered the primary genetic event leading to the malignant transformation of the plasma cells, has supported the idea that alteration of the class switch recombination (CSR) process could play a fundamental role in MM pathogenesis. The $X R C C 5$ gene encodes for the Ku80 protein, that together with $\mathrm{Ku} 70$ (XRCC6) constitutes the Ku70/Ku80 complex that acts in the recognition of double strand breaks (DSBs). The DNA breakpoints recognized by $\mathrm{Ku} 70 / \mathrm{Ku} 80$ are subsequently joined by the XRCC4/DNA ligase IV complex. Interestingly, some authors reported associations of XRCC4 (rs963248), XRCC5 (rs1051685) and LIG4 A3V (rs1805389), T9I (rs1805388) SNPs with MM susceptibility $(98,99)$. In particular, carriers of the XRCC4 rs963248 G allele as well as carriers of the XRCC5 
rs1051685 $\mathrm{G}$ allele showed an increased risk to develop MM (98), while heterozygotes for the LIG4 A3V SNP as well as rare homozygotes for the $L I G 4$ T9I SNP have been shown to have a lower susceptibility to MM (99). SNPs in BAX, CASP3 and $C A S P 9$ genes were found to be associated with MM risk in women $(95,101)$, while the $p 53$ codon 72 polymorphism (102) and SNPs in XRCC3 and ERCC2 genes $(98,100)$ showed no associations with MM risk.

Polymorphisms in xenobiotic metabolism and transport genes. SNPs in genes codifying for enzymes acting in phase I, phase II metabolic reactions and phase 0/III transport have been also investigated for associations with genetic susceptibility to MM. Glutathione-S-transferases (GSTs) conjugate phase I activated metabolites to favour their excretion from the organism. Polymorphisms in the GSTM1, GSTT1 and GSTP1 loci have been investigated in several case-control studies with weak evidence of association (102-105). Although not confirmed in other studies, Lincz et al showed an association between the GSTT1 null genotype and an increased MM risk. The authors also showed an association of both the rare homozygotes for the Q192R (rs662) SNP in the PON-1 genes and NAT2 rapid/slow phenotype with an increased risk of MM (105). In a following study on polymorphisms in genes involved in benzene metabolism Lincz et al evidenced an increased susceptibility to MM for carriers of 'high-risk genotypes/phenotypes' of GSTT1 (null), NQO1 (187PS/SS, rs1800566) and $m E H$ (high activity) genes as well as for the $\mathrm{G} / \mathrm{G}$ homozygotes for the $m E H \mathrm{H} 139 \mathrm{R}$ (rs2234922) polymorphism (106). Nevertheless, in another study investigating NQO1 P187S (rs1800566), PON-1 Q192R (rs622) and $m E H$ H139R (rs2234922) SNPs no associations were found (107).

Folate-metabolizing enzymes have been also intensely investigated in relation to MM risk. MTHFR, which has been found associated with cancer risk $(108,109)$, is one of the most important enzymes involved in the regulation of folate homeostasis. Two MTHFR missense SNPs, C677T (rs1801133) and A1298C (rs1801131), were investigated in relation to MM susceptibility in various reports with evidence for association (110-112) as well as for no association (113-117). Recently, a meta-analysis confirmed a possible role for the MTHFR C677T (rs1801133) SNP in MM susceptibility, with an increased risk for carriers of the $677 \mathrm{~T}$ allele (118). The minor allele $(\mathrm{G})$ of the missense substitution A2756G (rs1805057) in the enzyme methionine syntase (MS or MTR) has been found associated with higher risk of MM in a mixed Caucasian and AfricanAmerican population (112), but with decreased risk in an Asian population (114). However, this effect was not observed in a third study (117). SNPs in other genes such as $A B C B 1$, TYMS, CYPIAl and CYPIBI have been also investigated and showed modest evidence of association with MM risk $(107,112,114,119,120)$.

\section{Pharmacogenetics of multiple myeloma}

The study of pharmacogenetics in MM is relatively recent, the earliest studies dating back to early 2000. Several studies have explored factors influencing the individual response to chemotherapies and the resulting survival, while other studies have tried to further our understanding on adverse reaction to drugs.
Role of SNPs in therapy outcome and survival. Associations between several genetic variants and therapy outcome have been already reported. The TNF- $\alpha$ promoter SNP -238G/A (rs361525) has been associated with response to a thalidomide maintenance therapy in relapsed and refractory MM, showing a prolonged progression-free survival (PFS) and OS for carriers of the A allele (121). Interestingly, borderline association of $T N F-\alpha$ gene polymorphisms and PFS has been observed in previous studies $(78,79)$ and a significant association of the TNF- $\alpha-238 \mathrm{~A}$ allele with a better PFS and OS in patients treated with thalidomide and dexamethasone has been confirmed by recent findings (73).

Dasgupta et al showed association of the I105V (rs1695) SNP of the GSTP1 gene with a better PFS in MM patients homozygous for the $105 \mathrm{~V}$ allele after standard and high-dose chemotherapy (HDM) (122). A similar association between $105 \mathrm{~V}$ homozygotes for the GSTPI SNP I105V (rs1695) and MM outcome after DAV (dexamethasone/adriamycin/vincristine) induction therapy has also been described by others $(123,124)$.

Homozygotes for the T allele of TYMS +157C/T (rs699517) polymorphism have been shown to have a worse response to ASCT (124). An association with an improved outcome after HDM and ASCT in MM patients and a near-to-significance association with an improved OS for the T allele for the SNP rs1051296 in the folate transporters SLC19A1 gene has also been reported (125).

Due to their importance in the determination of drug bioavailability, drug metabolizing enzymes and drug transporters coding genes are among the most investigated for a role in MM pharmacogenetics. Among these, $A B C B 1$ has been widely studied. In particular the well known $A B C B 1 \mathrm{C} 3435 \mathrm{~T}$ (rs1045642) and G2677A/T (rs2032582) polymorphisms were found associated with outcome of different treatments in MM patients (123,126-128). The T allele of the $A B C B 1 \mathrm{C} 3435 \mathrm{~T}$ has been associated with a better response to DAV treatment (123), a better response and a better PFS (T/T homozygotes) after bortezomib treatment of relapsed and/or refractory myeloma patients $(128,129)$ and with better OS of MM patients $(130)$. The rare T allele of the triallelic $A B C B 1$ SNP G2677T/A has been associated to a better response to DAV (123) and a better OS (127) in MM patients.

SNPs in genes encoding drug metabolizing enzymes belonging to the cytochrome $\mathrm{P} 450$ family have been investigated as well (i.e., $C Y P 2 C 19, C Y P 2 D 6, C Y P 3 A 4)$ with controversial results $(123,126,131,132)$. In a study investigating two polymorphisms of $C Y P 2 C 19$ gene, poor metabolizer phenotype was associated with a poor response to thalidomide-based therapies (132). Vangsted et al showed the association of ERCC2 K751Q (rs1052559), XRCC3 T241M (rs861535), CD3EAP -21G/A (rs967591) (100) and IL1B -31T/C (rs1143627) (85) polymorphisms with outcome after ASCT in MM patients receiving HDM. In particular, carriers of the ERCC2 K751Q C allele, the variant T allele of $X R C C 3 \mathrm{~T} 241 \mathrm{M}$ and the A allele of $C D 3 E A P$ 21G/A SNP had a better time to treatment failure (TTF) in respect to homozygous wild-type carriers and the variant $\mathrm{A}$ allele of $C D 3 E A P$ 21G/A resulted also associated with a better OS (100). Carriers of the variant C allele for the ILIB -31T/C SNP showed a significantly improved OS than T carriers (85). A role of the NFKB1 -94 ins/delATTG polymorphism has been 
Table II. The IMMEnSE consortium participating centres.

Centres

Country

Hospital and Clinical Centres

Department of Oncology, Transplants and Advanced Technologies, Section of Haematology,

Pisa University Hospital

Department of Hematology, Medical University of Lodz

Division of Hematology, University Hospital of Salamanca

Department of Hematology and Hemotherapy, University Hospital Virgen de las Nieves

Hospices Civils de Lyon

Hospital de Braga

IDIBELL-Catalan Institute of Oncology and University of Barcelona

Research institutions

Genomic Epidemiology Group, DKFZ (German Cancer Research Center)

Genomic Oncology Area, GENYO (Pfizer-University of Granada-Andalusian Government Centre

for Genomics and Oncological Research)

Division of Genetics, Department of Biology, University of Pisa

International Agency for Research on Cancer IARC, Genetic Cancer Susceptibility Group

Life and Health Sciences Research Institute (ICVS), School of Health Sciences, University of Minho

Pisa, Italy

Lodz, Poland

Salamanca, Spain

Granada, Spain

Lyon, France

Braga, Portugal

Barcelona, Spain

Heidelberg, Germany

Granada, Spain

Pisa, Italy

Lyon, France

Braga, Portugal shown in patients receiving Interferon- $\alpha$ (IFN- $\alpha$ ) as maintenance therapy after HDM (133). Interestingly, in a recent study, Vangsted et al investigated additional genetic variants in the $I L 1 B$ promoter region and their impact on TTF, OS and IFN- $\alpha$ maintenance therapy. Carriers of the $\mathrm{T}$ allele of the $I L 1 B$ C-3737T (rs4848306) as well as carriers of the TGT haplotype resulting from the ILIB SNPs C-3737T, G-1464C (rs1143623) and T-31C (rs1143627) showed a reduced OS and TTF. In addition, carriers of the combination ILIB-3737T allele/ NFKB1 -94 delATTG alleles showed a better TTF and OS in patients treated with a IFN- $\alpha$ maintenance therapy (134). An association between the carriers of the $\mathrm{G}$ allele for the $-8 \mathrm{C} / \mathrm{G}$ SNP in the $20 \mathrm{~S}$ proteasome subunit coding gene PSMA6 and a better 5-year OS has been also shown (135). Recently, Du et al evidenced the association of the carriers of the A allele of the TRAF3 SNP rs11160707 with an improved PFS, while the variant alleles for two NFKB2 SNPs (rs12769316 and rs1056890) were associated, respectively, with an increased and a decreased OS (93).

Role of SNPS in treatment-related side effects and toxicity. Treatment-related neuropathy is one of the most common side effects in MM and affects about 40-64\% of the patients treated with bortezomib (136). Peripheral neuropathy has been registered also following thalidomide treatment in about $40 \%$ of the patients (137) and, at a minor grade, in patients treated with lenalidomide (138). Recently, Broyl et al showed several SNPs in different genes to be related with early- and lateonset bortezomib induced neuropathy. In particular, SNPs in CASP9 (rs4646091), RDM1 (rs2251660), ALOX12 (rs1126667, rs434473), LSMI (rs7823144), IGFR1 (rs1879612) and NEK4 (rs1029871) genes associated with early-onset bortezomib induced neuropathy, while SNPs in ERCC4 (rs1799800, rs1799801), SRD5A2 (rs2300697), IFNGR2 (rs1059293), ERCC3 (rs2276583), ATM (rs189037, rs664677, rs664982),
MRE11A (rs10501815), SELP (rs6131), PTPRN2 (rs1130499), STK31 (rs4722266) and PPARD (rs2267668) genes associated with late-onset bortezomib induced neuropathy (139). Several authors investigated the role of genetic variation in thalidomide-related adverse effects. Johnson et al analyzed a panel of over 3,400 SNPs in 964 genes in 1,495 patients from different clinical trials, showing overall associations of SNPs in SERPINE1 (rs7242), ADRB2 (rs2082382, rs1042714), ID3 (rs1555026), CYP2C9 (rs1934951), CAMKK1 (rs7214723), CYP2C8 (rs1058932), SLC10A2 (rs2301157) and NFATC2 (rs228832) genes with thalidomide-related neuropathy (140). The same SNP panel has been used to investigate the role of genetic variation in the occurrence of thalidomide-related venous thrombotic events (VTEs). The results showed a total of 18 SNPs, validated in 2 patient groups from different clinical trials, associated with the occurrence of VTEs in thalidomide treated patients (141). The use of bisphosphonates in MM could be associated with the development of osteonecrosis of the jaw (ONJ) (142) and Sarasquete et al showed a statistically significant association of the CYP2C8 SNP rs1934951 with the occurrence of ONJ (143).

\section{Limits and perspectives: the rationale for the IMMEnSE consortium}

Despite several efforts towards the comprehension of the role of common genetic variability in modifying the individual risk to develop MM, to date no locus has been unequivocally established as risk factor for MM development. The fairly small sample sizes (ranging from 26 to 352 cases) of the published studies, due in part to the low incidence of the disease, could represent one fundamental limiting factor to detect genetic associations with MM risk. This is particularly important considering the fact that the genetic risk to develop $\mathrm{MM}$ is likely influenced by low-penetrance variants the 
effect of which is difficult to detect in uncommon diseases. Moreover, this limit can explain, at least in part, the failure of the replication effort suffered by several studies so far reported. Even if meta-analyses can overcome the size limits that occur in single studies, limited data exist to date. One viable option to further our understanding in the genetic determinants of $\mathrm{MM}$ risk is to unify a large set of patients across different populations and cohorts in a consortium. This strategy has been shown to be successful for various cancer sites, as shown on one hand by several GWAS in which several new risk loci were discovered $(144,145)$ and on the other hand by various candidate gene studies nested in large cohorts used to replicate or disproof known findings (146). This effort is of the uttermost importance for a low-prevalence disease such as MM. Moreover, a large collection of samples possibly joined by a meticulous collection of co-variates of clinical importance, not only provides a greater advantage in terms of power for risk study, but allows also a more exhaustive investigation of pharmacogenetics. Given the heterogeneity of the treatments in the patient populations, the possibility to unite several sets of patients allows the individuation of larger subgroups receiving similar therapies.

The IMMEnSE consortium. The International Multiple Myeloma rESEarch (IMMEnSE) consortium aims to improve the understanding of genetics and pharmacogenetics of MM. The driving idea of the IMMEnSE consortium is to join together the efforts of different research groups with the constitution of a large bio- and databank to allow more powerful and meaningful investigations able to uncover the role played by genetic variants in MM genetics, as successfully done for other diseases $(147,148)$. To date, the IMMEnSE consortium brings together twelve basic and/or clinical research groups with a wide spectrum of expertise and spreads widely across six European countries (Table II). Recognizing the need for further expansion of this network, the recruiting of collaborators and partner institutions is continuously ongoing.

The cases included in the consortium population are defined by a confirmed diagnosis of MM, according to the International Myeloma Working Group (IMWG) criteria (1). For each patient, information about gender, age at diagnosis, $\beta 2$-microglobulin, albumin, creatinin, haemoglobin, bone lesions and previous clinical history at diagnosis are collected. Detailed information concerning front line and relapsed/ refractory patients therapies are collected, as well as the individual response to them. PFS from ASCT, OS and toxicity events are registered as well to investigate the role of genetic variants in the pharmacogenetics of MM. Moreover, with the aim to investigate genetic variables involved in the transition from MGUS to MM, positive history of MGUS is registered. So far, 743 MM cases diagnosed between 1992 and 2010 have been retrospectively recruited in each participating centre up to now and collected at the German Cancer Research Center, where the DNA bank and the central database have been set up. The collection of MM and MGUS cases is currently ongoing in every participating centre and the population is expected to reach 2000 cases within 3 years.

Different region-specific subpopulations of unmatched controls have been selected for a total of 950 healthy individuals

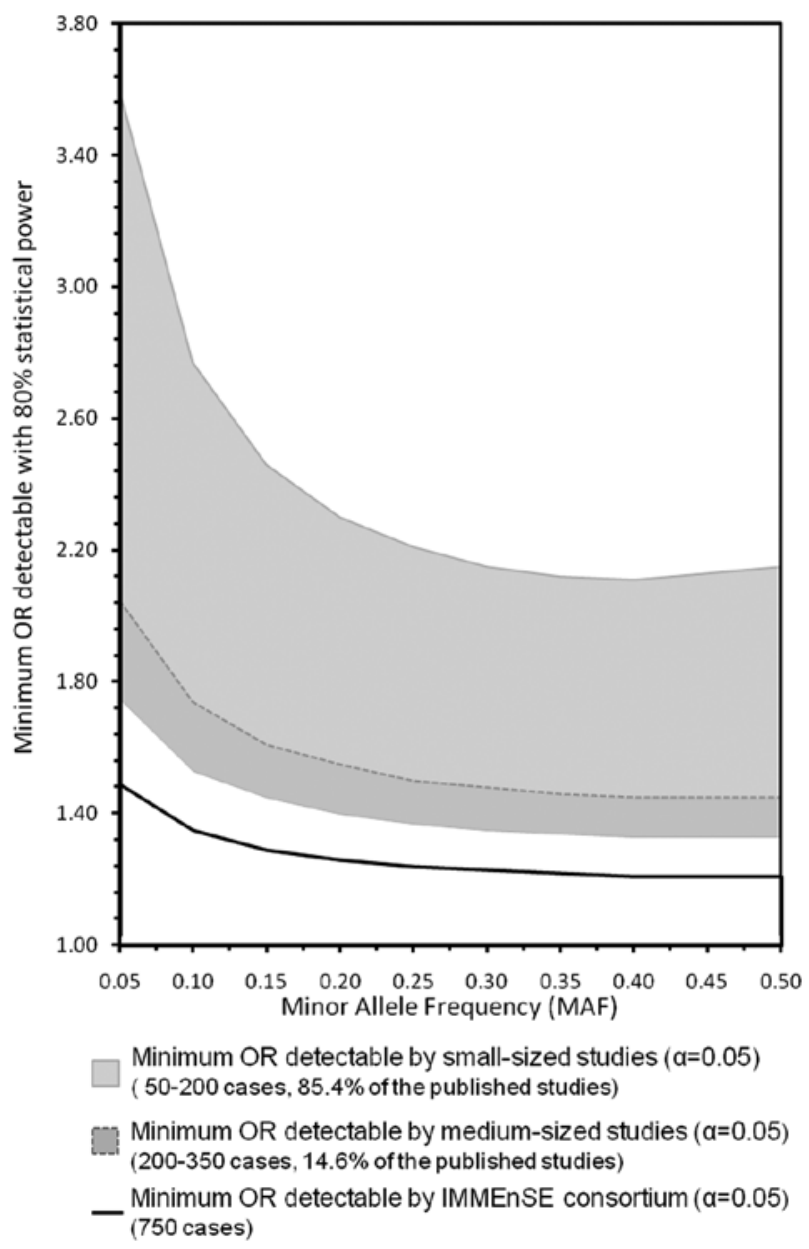

Figure 1. Statistical power of genetic association studies on MM $(\alpha=0.05)$. This figure describes the minimum OR detectable with a power of $80 \%$ and a MAF from 0.05 to 0.5 with a type I error $\alpha=0.05$, depending on the sample size. The minimum OR detectable decreases considerably with larger sample sizes. The IMMEnSE population ensures the statistical power to detect possible associations between low-penetrance genetic variants and MM risk.

enrolled to date. Controls have been selected among the general population as well as among hospitalized subjects with different diagnosis excluding cancer. Gender and age at recruitment are collected for every subject enrolled. For each subject, informed consent to collect fresh blood and perform DNA extraction for research purpose has been requested and collected individually by each centre. Genetic analyses are being performed in the German Cancer Research Center (Heidelberg, Germany). Detailed information on the demographic and clinical characteristics of the IMMEnSE consortium population are described in Table III.

\section{Future directions}

Epidemiological studies have been shown to be of great value to the understanding of the biology of many other cancer types. The available results on genetic risk of MM clearly evidence the necessity of additional studies assessing also the interplay of genetic and clinical factors to fully understand the molecular mechanisms underlying the susceptibility to MM. At the same time, the consortium aims to contribute to the understanding 
Table III-A. Demographic and clinical characteristics of MM cases.

\begin{tabular}{|c|c|c|c|c|c|c|c|}
\hline \multirow[b]{2}{*}{ Characteristics } & \multicolumn{7}{|c|}{ Cases } \\
\hline & $1^{\mathrm{a}}$ & $2^{\mathrm{a}}$ & $3^{\mathrm{a}}$ & $4^{\mathrm{a}}$ & $5^{\mathrm{a}}$ & $6^{\mathrm{a}}$ & $\mathrm{All}^{\mathrm{a}}$ \\
\hline \multicolumn{8}{|l|}{ Age at diagnosis (years) } \\
\hline Mean $( \pm$ SD) & $62.53( \pm 9.93)$ & $61.85( \pm 10.41)$ & $62.88( \pm 11.75)$ & $64.25( \pm 9.90)$ & $55.96( \pm 9.31)$ & $66.78( \pm 10.49)$ & $61.34( \pm 10.38)$ \\
\hline Median (range) & $63(35-87)$ & $62(39-86)$ & $62(31-93)$ & $64(39-86)$ & $58(27-75)$ & $68(43-86)$ & $62(27-93)$ \\
\hline \multicolumn{8}{|l|}{ Gender N (\%) } \\
\hline Male & $122(52.3)$ & $71(49.3)$ & $67(52.3)$ & $39(42.8)$ & $52(56.5)$ & $26(47.3)$ & $377(50.7)$ \\
\hline Female & $111(47.7)$ & $73(50.7)$ & $61(47.7)$ & $52(57.2)$ & $40(43.5)$ & $29(52.7)$ & $366(49.3)$ \\
\hline Total & $233(31.4)$ & $144(19.4)$ & $128(17.2)$ & $91(12.2)$ & $92(12.4)$ & $55(7.4)$ & $743(100)$ \\
\hline Ascertainment period & 1992-2009 & 1993-2009 & 1990-2009 & 1991-2006 & $1995-2005$ & $2007-2010$ & $1990-2010$ \\
\hline \multicolumn{8}{|l|}{ Stage at diagnosis $(\%)$} \\
\hline $\begin{array}{l}\text { Durie-Salmon } \\
\text { I/II/III/ND }\end{array}$ & \multicolumn{7}{|c|}{$15.1 / 21.4 / 63.5 / 48.3$} \\
\hline $\begin{array}{l}\text { ISS } \\
\text { I/II/III/ND }\end{array}$ & \multicolumn{7}{|c|}{$52.9 / 23.0 / 24.1 / 76.6$} \\
\hline \multicolumn{8}{|l|}{ Prognostic markers } \\
\hline$\beta 2$-microglobulin $(\mu \mathrm{g} / \mathrm{l})$ & \multicolumn{7}{|c|}{ ) $3.39(1.99-5.90)^{\mathrm{b}}$} \\
\hline Creatinin (mg/dl) & \multicolumn{7}{|c|}{$1.0(0.8-1.3)^{\mathrm{b}}$} \\
\hline Albumin $(\mathrm{g} / \mathrm{dl})$ & \multicolumn{7}{|c|}{$3.9(3.5-14.6)^{\mathrm{b}}$} \\
\hline Haemoglobin (mg/dl) & \multicolumn{7}{|c|}{$10.8(8.8-12.7)^{\mathrm{b}}$} \\
\hline
\end{tabular}

B, Demographic characteristics of controls by population.

\begin{tabular}{|c|c|c|c|c|c|c|}
\hline \multirow[b]{2}{*}{ Characteristics } & \multicolumn{6}{|c|}{ Controls } \\
\hline & Italian & Polish & Spanish & French & Portuguese & All \\
\hline \multicolumn{7}{|l|}{$\begin{array}{l}\text { Age at diagnosis } \\
\text { (years) }\end{array}$} \\
\hline Mean $( \pm$ SD $)$ & $58.81( \pm 10.95)$ & $69.50( \pm 6.67)$ & $65.21( \pm 13.45)$ & $53.12( \pm 6.28)$ & $60.68( \pm 7.72)$ & $57.11(16.09)$ \\
\hline Median (range) & $59(35-89)$ & $69(55-98)$ & $66(24-92)$ & $51.5(41-68)$ & $58(51-85)$ & $59(18-98)$ \\
\hline \multicolumn{7}{|l|}{ Gender N (\%) } \\
\hline Male & $131(52.3)$ & $69(49.3)$ & $173(52.3)$ & $68(52.5)$ & $55(56.5)$ & $476(52.1)$ \\
\hline Female & $106(47.7)$ & $81(50.7)$ & $158(47.7)$ & $64(48.5)$ & $45(43.5)$ & 437 (47.9) \\
\hline Total & $237(25.0)$ & $150(15.8)$ & $331(34.8)$ & $132(13.9)$ & $100(10.5)$ & 950 \\
\hline Control type & $\begin{array}{c}\text { General } \\
\text { population }\end{array}$ & $\begin{array}{l}\text { Blood } \\
\text { donors }\end{array}$ & Hospitalized & $\begin{array}{l}\text { Blood } \\
\text { donors }\end{array}$ & $\begin{array}{l}\text { Blood } \\
\text { donors }\end{array}$ & \\
\hline
\end{tabular}

${ }^{a} 1$, Department of Oncology, Transplants and Advanced Technologies, Section of Haematology, Pisa University Hospital, Pisa, Italy; 2, Department of Hematology, Medical University of Lodz, Lodz, Poland; 3, Division of Hematology, University Hospital of Salamanca, Salamanca, Spain; 4, Department of Hematology and Hemotherapy, University Hospital Virgen de las Nieves, Granada, Spain; 5, Hospices Civils de Lyon, Lyon, France;

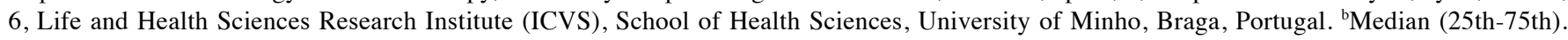
$\mathrm{ND}$, no data.

of how the genotype may predict the clinical outcome and the degree of response to treatments, in order to offer new clues to optimize treatment and to improve patients' lives. Thus, the IMMEnSE consortium will also allow the optimization of the efforts towards the translational implementation of genetic findings.
Replication of best associated SNPs. In the proposed framework of the IMMEnSE consortium, the first objective is to conduct a comprehensive replication of the most important and significant genetic associations found with MM risk. As shown in Fig. 1, the current size of the IMMEnSE population is already enough to guarantee a statistical power over $80 \%$ 
for the identification of an OR of 1.5 with a Minor Allele Frequency (MAF) of 0.05 , up to an OR of 1.25 with a MAF of 0.25 or greater. Besides, taking into account the ongoing recruitment of MM cases, this power is destined to grow. Thus, these results should make a significant improvement to the interpretation of the controversial results published to date.

GWAS, validation of associated loci and rare SNP analysis. The contribution of GWAS in the identification of new loci associated with risk of several cancer types has been of extreme importance in the last few years. Up to date, no GWAS has been conducted on MM. As soon as GWAS data will be available also for MM risk, the IMMEnSE population will constitute a valuable tool for replication and confirmation of the most interesting results. Moreover, given that GWAS studies still lack the coverage of less common variants (i.e., MAF $<5 \%$ ), their investigation in candidate-gene approach studies will still be of primary importance in MM genetic risk assessment. In this context, the aim of the IMMEnSE consortium will be to investigate genetic variants in regions shown to be possible actors in the pathogenesis of MM.

Identification of tagged functional variants. Tagging SNPs are unlikely to be directly responsible for the effect seen on disease risk. The identification of functional genetic variants associated with tag SNPs is one of the most fascinating and important challenges in the near future. While tag SNPs can sufficiently cover linkage disequilibrium (LD) blocks within a region, direct sequencing or fine mapping of the associated loci are often needed to determine the effective genetic variants able to impact the MM risk. Availability of samples from MM cases will be paramount for these tasks, both to perform sequencing of targeted regions in order to discover potentially causal variants and/or to test whether such candidate variants show a stronger association than tag SNPs identified by GWAS.

Multifactorial risk scores. The impact of common lowpenetrance variants taken individually is expected to be very small. Nevertheless, the interactions of many modest contributions could lead to a significant improvement of MM risk. The cumulative risk could be determined from interactions between genetic variants as well as from the interaction of genetic and environmental factors. The evaluation of geneenvironment interactions according to a multiplicative or supra-multiplicative statistical model requires very large sample size to ensure an adequate power. However, the population collected in the context of the IMMEnSE consortium offers the possibility to build multifactorial risk scores based on additive models that take into account both genetic factors and clinical variables and evaluate their predictive power. This could lead to the identification of MM susceptibility models able to describe and better predict the risk of MM.

The identification of 'easy-to-use' prognostic markers. To establish clear and effective prognostic factors for staging, outcome and survival of MM patients remains one of the most important issues to be addressed. Genetic markers offer the great advantage to be easily determinable and invariant over time. Thus, they appear to be ideal candidates to be employed as fast markers in screening, prevention and diagnosis of diseases. Even if with the data currently available on MM we are still far from this goal, the translational potential of pharmacogenetics appears to be relevant. In the context of the IMMEnSE consortium, clinical parameters at diagnosis, response to treatments, PFS and OS will be evaluated in relation to genetic variants studied to individuate new genetic prognostic markers.

\section{Acknowledgements}

We acknowledge support by the recruiting hospitals and physicians of the study regions as well as their collaborating nurses and technicians. Collection of blood samples from Spain, patients from Granada area and DNA extraction was partially supported by grants P08-CVI-4116 from Consejería de Salud de la Junta de Andalucia (Sevilla, Spain) and PI081051 from Fondo de Investigaciones Sanitarias (Madrid, Spain). Collection of blood samples from Polish patients and controls from Lodz area and DNA extraction was supported by a grant from Polish Ministry of Science and Higher Education (No. NN402178334).

\section{References}

1. International Myeloma Working Group: Criteria for the classification of monoclonal gammopathies, multiple myeloma and related disorders: a report of the International Myeloma Working Group. Br J Haematol 121: 749-757, 2003.

2. Raab MS, Podar K, Breitkreutz I, Richardson PG and Anderson KC: Multiple myeloma. Lancet 374: 324-339, 2009.

3. Ferlay J, Parkin DM and Steliarova-Foucher E: Estimates of cancer incidence and mortality in Europe in 2008. Eur J Cancer 46: 765-781, 2010.

4. Ferlay J, Shin HR, Bray F, Forman D, Mathers C and Parkin DM: Estimates of worldwide burden of cancer in 2008: GLOBOCAN 2008. Int J Cancer 127: 2893-2917, 2010.

5. Jemal A, Bray F, Center MM, Ferlay J, Ward E and Forman D: Global cancer statistics. CA Cancer J Clin 61: 69-90, 2011.

6. Avet-Loiseau H, Li C, Magrangeas F, et al: Prognostic significance of copy-number alterations in multiple myeloma. J Clin Oncol 27: 4585-4590, 2009.

7. Parkin DM and Muir CS: Cancer incidence in five continents. Comparability and quality of data. IARC Sci Publ, pp45-173, 1992 .

8. Alexander DD, Mink PJ, Adami HO, et al: Multiple myeloma: a review of the epidemiologic literature. Int J Cancer 120 (Suppl 12): S40-S61, 2007.

9. Altekruse SF, Kosary CL, Krapcho M, et al (eds): SEER Cancer Statistics Review, 1975-2007. National Cancer Institute, Bethesda, 2010.

10. Davey Smith G, Neaton JD, Wentworth D, Stamler R and Stamler J: Mortality differences between black and white men in the USA: contribution of income and other risk factors among men screened for the MRFIT. MRFIT Research Group. Multiple Risk Factor Intervention Trial. Lancet 351: 934-939, 1998.

11. Ries LAG, Eisner MP, Kosary CL, et al (eds): SEER Cancer Statistics Review, 1975-2002. National Cancer Institute, Bethesda, 2005.

12. Bergsagel D: The incidence and epidemiology of plasma cell neoplasms. Stem Cells 13 (Suppl 2): S1-S9, 1995.

13. Ludwig H, Bolejack V, Crowley J, et al: Survival and years of life lost in different age cohorts of patients with multiple myeloma. $\mathrm{J}$ Clin Oncol 28: 1599-1605, 2010.

14. Ludwig H, Durie BG, Bolejack V, et al: Myeloma in patients younger than age 50 years presents with more favorable features and shows better survival: an analysis of 10549 patients from the International Myeloma Working Group. Blood 111: 4039-4047, 2008.

15. Landgren O, Kyle RA, Pfeiffer RM, et al: Monoclonal gammopathy of undetermined significance (MGUS) consistently precedes multiple myeloma: a prospective study. Blood 113: 5412-5417, 2009. 
16. Weiss BM, Abadie J, Verma P, Howard RS and Kuehl WM: A monoclonal gammopathy precedes multiple myeloma in most patients. Blood 113: 5418-5422, 2009.

17. Kyle RA, Therneau TM, Rajkumar SV, et al: Prevalence of monoclonal gammopathy of undetermined significance. N Engl J Med 354: 1362-1369, 2006.

18. Kuehl WM and Bergsagel PL: Multiple myeloma: evolving genetic events and host interactions. Nat Rev Cancer 2: 175-187, 2002.

19. Kyle RA, Therneau TM, Rajkumar SV, Larson DR, Plevak MF and Melton LJ III: Long-term follow-up of 241 patients with monoclonal gammopathy of undetermined significance: the original Mayo Clinic series 25 years later. Mayo Clin Proc 79: 859-866, 2004

20. Kyle RA and Greipp PR: Smoldering multiple myeloma. N Engl J Med 302: 1347-1349, 1980.

21. Kyle RA and Rajkumar SV: Criteria for diagnosis, staging, risk stratification and response assessment of multiple myeloma. Leukemia 23: 3-9, 2009.

22. Martinez-Lopez J, Blade J, Mateos MV, et al: Long-term prognostic significance of response in multiple myeloma after stem cell transplantation. Blood 118: 529-534, 2011.

23. Rajkumar SV: Treatment of myeloma: cure vs control. Mayo Clin Proc 83: 1142-1145, 2008

24. Gay F, Larocca A, Wijermans P, et al: Complete response correlates with long-term progression-free and overall survival in elderly myeloma treated with novel agents: analysis of 1175 patients. Blood 117: 3025-3031, 2011.

25. Singhal S, Mehta J, Desikan R, et al: Antitumor activity of thalidomide in refractory multiple myeloma. N Engl J Med 341 $1565-1571,1999$.

26. Richardson PG, Barlogie B, Berenson J, et al: A phase 2 study of bortezomib in relapsed, refractory myeloma. N Engl J Med 348 2609-2617, 2003.

27. Rajkumar SV, Hayman SR, Lacy MQ, et al: Combination therapy with lenalidomide plus dexamethasone (Rev/Dex) for newly diagnosed myeloma. Blood 106: 4050-4053, 2005.

28. Rajkumar SV, Richardson PG, Hideshima T and Anderson KC: Proteasome inhibition as a novel therapeutic target in human cancer. J Clin Oncol 23: 630-639, 2005

29. Quach H, Ritchie D, Stewart AK, et al: Mechanism of action of immunomodulatory drugs (IMiDS) in multiple myeloma. Leukemia 24: 22-32, 2010.

30. Palumbo A and Anderson K: Multiple myeloma. N Engl J Med 364: 1046-1060, 2011

31. Ferlay J, Bray F, Sankila R and Parkin DM: EUCAN: Cancer Incidence Mortality and Prevalence in the European Union 1998. IARC Press, Lyon, 1999.

32. Larsson SC and Wolk A: Body mass index and risk of multiple myeloma: a meta-analysis. Int J Cancer 121: 2512-2516, 2007.

33. Wallin A and Larsson SC: Body mass index and risk of multiple myeloma: a meta-analysis of prospective studies. Eur J Cancer 47: 1606-1615, 2011.

34. Fritschi L, Ambrosini GL, Kliewer EV, Johnson KC and Canadian Cancer Registries Epidemiologic Research Group: Dietary fish intake and risk of leukaemia, multiple myeloma, and non-Hodgkin lymphoma. Cancer Epidemiol Biomarkers Prev 13 532-537, 2004

35. Hosgood HD III, Baris D, Zahm SH, Zheng T and Cross AJ: Diet and risk of multiple myeloma in Connecticut women. Cancer Causes Control 18: 1065-1076, 2007.

36. Pekmezovic T, Vlajinac H, Adanja B, et al: Dietary factors and multiple myeloma. Case-control study in Belgrade. IARC Sci Publ 156: 231-232, 2002.

37. Eriksson M: Rheumatoid arthritis as a risk factor for multiple myeloma: a case-control study. Eur J Cancer 29A: 259-263, 1993

38. Matteson EL, Hickey AR, Maguire L, Tilson $\mathrm{HH}$ and Urowitz MB: Occurrence of neoplasia in patients with rheumatoid arthritis enrolled in a DMARD Registry. Rheumatoid Arthritis Azathioprine Registry Steering Committee. J Rheumatol 18 : 809-814, 1991.

39. Dal Maso L and Franceschi S: Epidemiology of non-Hodgkin lymphomas and other haemolymphopoietic neoplasms in people with AIDS. Lancet Oncol 4: 110-119, 2003.

40. Cheung MC, Pantanowitz L and Dezube BJ: AIDS-related malignancies: emerging challenges in the era of highly active antiretroviral therapy. Oncologist 10: 412-426, 2005.

41. Simard EP, Pfeiffer RM and Engels EA: Cumulative incidence of cancer among individuals with acquired immunodeficiency syndrome in the United States. Cancer 117: 1089-1096, 2011.
42. Perrotta C, Staines A and Cocco P: Multiple myeloma and farming. A systematic review of 30 years of research. Where next? J Occup Med Toxicol 3: 27, 2008.

43. Khuder SA and Mutgi AB: Meta-analyses of multiple myeloma and farming. Am J Ind Med 32: 510-516, 1997.

44. Gold LS, Milliken K, Stewart P, et al: Occupation and multiple myeloma: an occupation and industry analysis. Am J Ind Med 53: 768-779, 2010

45. Lope V,Perez-Gomez B, Aragones N, et al: Occupation, exposure to chemicals, sensitizing agents, and risk of multiple myeloma in Sweden. Cancer Epidemiol Biomarkers Prev 17: 3123-3127, 2008.

46. Orsi L, Delabre L, Monnereau A, et al: Occupational exposure to pesticides and lymphoid neoplasms among men: results of a French case-control study. Occup Environ Med 66: 291-298, 2009.

47. Brown LM, Burmeister LF, Everett GD and Blair A: Pesticide exposures and multiple myeloma in Iowa men. Cancer Causes Control 4: 153-156, 1993.

48. Baris D, Silverman DT, Brown LM, et al: Occupation, pesticide exposure and risk of multiple myeloma. Scand J Work Environ Health 30: 215-222, 2004

49. Semenciw RM, Morrison HI, Riedel D, Wilkins K, Ritter L and Mao Y: Multiple myeloma mortality and agricultural practices in the Prairie provinces of Canada. J Occup Med 35: 557-561, 1993.

50. Bond GG, Bodner KM, Olsen GW and Cook RR: Mortality among workers engaged in the development or manufacture of styrene-based products - an update. Scand J Work Environ Health 18: 145-154, 1992

51. Grodstein F, Hennekens CH, Colditz GA, Hunter DJ and Stampfer MJ: A prospective study of permanent hair dye use and hematopoietic cancer. J Natl Cancer Inst 86: 1466-1470, 1994.

52. Massoudi BL, Talbott EO, Day RD, Swerdlow SH, Marsh GM and Kuller LH: A case-control study of hematopoietic and lymphoid neoplasms: the role of work in the chemical industry. Am J Ind Med 31: 21-27, 1997.

53. Thun MJ, Altekruse SF, Namboodiri MM, Calle EE, Myers DG and Heath CW Jr: Hair dye use and risk of fatal cancers in U.S. women. J Natl Cancer Inst 86: 210-215, 1994.

54. Torchio P, Lepore AR, Corrao G, et al: Mortality study on a cohort of Italian licensed pesticide users. Sci Total Environ 149: 183-191, 1994

55. Viel JF and Richardson ST: Lymphoma, multiple myeloma and leukaemia among French farmers in relation to pesticide exposure. Soc Sci Med 37: 771-777, 1993.

56. Mills PK, Newell GR, Beeson WL, Fraser GE and Phillips RL: History of cigarette smoking and risk of leukemia and myeloma: results from the Adventist health study. J Natl Cancer Inst 82: 1832-1836, 1990.

57. Brown LM, Gibson R, Burmeister LF, Schuman LM, Everett GD and Blair A: Alcohol consumption and risk of leukemia, nonHodgkin's lymphoma, and multiple myeloma. Leuk Res 16: 979-984, 1992.

58. Ichimaru M, Ishimaru T, Mikami M and Matsunaga M: Multiple myeloma among atomic bomb survivors in Hiroshima and Nagasaki, 1950-76: relationship to radiation dose absorbed by marrow. J Natl Cancer Inst 69: 323-328, 1982.

59. Stagnaro E, Ramazzotti V, Crosignani P, et al: Smoking and hematolymphopoietic malignancies. Cancer Causes Control 12: 325-334, 2001.

60. Brown LM, Pottern LM, Silverman DT, et al: Multiple myeloma among Blacks and Whites in the United States: role of cigarettes and alcoholic beverages. Cancer Causes Control 8: 610-614, 1997.

61. Preston DL, Kusumi S, Tomonaga M, et al: Cancer incidence in atomic bomb survivors. Part III. Leukemia, lymphoma and multiple myeloma, 1950-1987. Radiat Res 137: S68-S97, 1994.

62. Judson IR, Wiltshaw E and Newland AC: Multiple myeloma in a pair of monozygotic twins: the first reported case. Br J Haematol 60: $551-554,1985$.

63. Landgren O, Linet MS, McMaster ML, Gridley G, Hemminki K and Goldin LR: Familial characteristics of autoimmune and hematologic disorders in 8,406 multiple myeloma patients: a population-based case-control study. Int J Cancer 118: 3095-3098, 2006.

64. Eriksson M and Hallberg B: Familial occurrence of hematologic malignancies and other diseases in multiple myeloma: a casecontrol study. Cancer Causes Control 3: 63-67, 1992.

65. Brown LM, Linet MS, Greenberg RS, et al: Multiple myeloma and family history of cancer among blacks and whites in the U.S. Cancer 85: 2385-2390, 1999. 
66. Ogmundsdottir HM, Haraldsdottirm V, Johannesson GM, et al: Familiality of benign and malignant paraproteinemias. A population-based cancer-registry study of multiple myeloma families. Haematologica 90: 66-71, 2005.

67. Lynch HT, Watson P, Tarantolo S, et al: Phenotypic heterogeneity in multiple myeloma families. J Clin Oncol 23: 685-693, 2005.

68. Kristinsson SY, Bjorkholm M, Goldin LR, et al: Patterns of hematologic malignancies and solid tumors among 37,838 firstdegree relatives of 13,896 patients with multiple myeloma in Sweden. Int J Cancer 125: 2147-2150, 2009.

69. Landgren O, Kristinsson SY, Goldin LR, et al: Risk of plasma cell and lymphoproliferative disorders among 14621 first-degree relatives of 4458 patients with monoclonal gammopathy of undetermined significance in Sweden. Blood 114: 791-795, 2009.

70.Zheng C, Huang DR, Bergenbrant S, et al: Interleukin 6, tumour necrosis factor $\alpha$, interleukin $1 \beta$ and interleukin 1 receptor antagonist promoter or coding gene polymorphisms in multiple myeloma. Br J Haematol 109: 39-45, 2000.

71. Lee KM, Baris D, Zhang Y, et al: Common single nucleotide polymorphisms in immunoregulatory genes and multiple myeloma risk among women in Connecticut. Am J Hematol 85 560-563, 2010.

72.Zheng C, Huang D, Liu L, et al: Interleukin-10 gene promoter polymorphisms in multiple myeloma. Int J Cancer 95: 184-188, 2001.

73. Du J, Yuan Z, Zhang C, et al: Role of the TNF- $\alpha$ promoter polymorphisms for development of multiple myeloma and clinica outcome in thalidomide plus dexamethasone. Leuk Res 34: 1453-1458, 2010.

74. Demeter J, Messer G, Ramisch S, et al: Polymorphism within the second intron of the IL-1 receptor antagonist gene in patients with hematopoietic malignancies. Cytokines Mol Ther 2 : 239-242, 1996.

75. Cozen W, Gebregziabher M, Conti DV, et al: Interleukin6-related genotypes, body mass index, and risk of multiple myeloma and plasmacytoma. Cancer Epidemiol Biomarkers Prev 15: 2285-2291, 2006

76. Duch CR, Figueiredo MS, Ribas C, Almeida MS, Colleoni GW and Bordin JO: Analysis of polymorphism at site $-174 \mathrm{G} / \mathrm{C}$ of interleukin- 6 promoter region in multiple myeloma. Braz J Med Biol Res 40: 265-267, 2007.

77. Abazis-Stamboulieh D, Oikonomou P, Papadoulis N, Panayiotidis P, Vrakidou E and Tsezou A: Association of interleukin-1A, interleukin-1B and interleukin-1 receptor antagonist gene polymorphisms with multiple myeloma. Leuk Lymphoma 48: 2196-2203, 2007.

78. Davies FE, Rollinson SJ, Rawstron AC, et al: High-producer haplotypes of tumor necrosis factor alpha and lymphotoxin alpha are associated with an increased risk of myeloma and have an improved progression-free survival after treatment. J Clin Oncol 18: 2843-2851, 2000.

79. Morgan GJ, Adamson PJ, Mensah FK, et al: Haplotypes in the tumour necrosis factor region and myeloma. Br J Haematol 129: 358-365, 2005.

80. Mazur G, Bogunia-Kubik K, Wrobel T, et al: IL-6 and IL-10 promoter gene polymorphisms do not associate with the susceptibility for multiple myeloma. Immunol Lett 96: 241-246, 2005.

81. Aladzsity I, Kovacs M, Semsei A, et al: Comparative analysis of IL6 promoter and receptor polymorphisms in myelodysplasia and multiple myeloma. Leuk Res 33: 1570-1573, 2009.

82. Birmann BM, Tamimi RM, Giovannucci E, et al: Insulin-like growth factor-1- and interleukin-6-related gene variation and risk of multiple myeloma. Cancer Epidemiol Biomarkers Prev 18: 282-288, 2009.

83. Kadar K, Kovacs M, Karadi I, et al: Polymorphisms of TNF-alpha and LT-alpha genes in multiple myeloma. Leuk Res 32: 1499-1504, 2008.

84.Pratt G, Fenton JA, Allsup D, et al: A polymorphism in the 3' UTR of IRF4 linked to susceptibility and pathogenesis in chronic lymphocytic leukaemia and Hodgkin lymphoma has limited impact in multiple myeloma. Br J Haematol 150 371-373, 2010

85. Vangsted AJ, Klausen TW, Ruminski W, et al: The polymorphism IL-1 $\beta$ T-31C is associated with a longer overall survival in patients with multiple myeloma undergoing auto-SCT. Bone Marrow Transplant 43: 539-545, 2009.

86. Brown EE, Lan Q, Zheng T, et al: Common variants in genes that mediate immunity and risk of multiple myeloma. Int J Cancer 120: 2715-2722, 2007.
87. Bommert K, Bargou RC and Stuhmer T: Signalling and survival pathways in multiple myeloma. Eur J Cancer 42: 1574-1580, 2006.

88. Podar K, Chauhan D and Anderson KC: Bone marrow microenvironment and the identification of new targets for myeloma therapy. Leukemia 23: 10-24, 2009.

89. Li ZW, Chen H, Campbell RA, Bonavida B and Berenson JR: NF-kappaB in the pathogenesis and treatment of multiple myeloma. Curr Opin Hematol 15: 391-399, 2008.

90. Chng WJ, Glebov O, Bergsagel PL and Kuehl WM: Genetic events in the pathogenesis of multiple myeloma. Best Pract Res Clin Haematol 20: 571-596, 2007.

91. Parker KM, Ma MH, Manyak S, et al: Identification of polymorphisms of the $I \kappa B \alpha$ gene associated with an increased risk of multiple myeloma. Cancer Genet Cytogenet 137: 43-48, 2002.

92. Spink CF, Gray LC, Davies FE, Morgan GJ and Bidwell JL: Haplotypic structure across the IкB $\alpha$ gene (NFKBIA) and association with multiple myeloma. Cancer Lett 246: 92-99, 2007.

93. Du J, Huo J, Shi J, et al: Polymorphisms of NF- $\mathrm{B}$ family genes are associated with development of multiple myeloma and treatment outcome in patients undergoing bortezomib-based regimens. Haematologica 96: 729-737, 2011

94. Purdue MP, Lan Q, Menashe I, et al: Variation in innate immunity genes and risk of multiple myeloma. Hematol Oncol 29: 42-46, 2011.

95. Hosgood HD III, Baris D, Zhang Y, et al: Genetic variation in cell cycle and apoptosis related genes and multiple myeloma risk. Leuk Res 33: 1609-1614, 2009.

96. Ostrovsky O, Korostishevsky M, Levite I, et al: Association of heparanase gene (HPSE) single nucleotide polymorphisms with hematological malignancies. Leukemia 21: 2296-2303, 2007.

97. Pemberton NC, Paneesha S, Hiller L, et al: The SDF-1 G > A polymorphism at position 801 plays no role in multiple myeloma but may contribute to an inferior cause-specific survival in chronic lymphocytic leukemia. Leuk Lymphoma 47: 1239-1244, 2006.

98. Hayden PJ, Tewari P, Morris DW, et al: Variation in DNA repair genes XRCC3, XRCC4, XRCC5 and susceptibility to myeloma. Hum Mol Genet 16: 3117-3127, 2007.

99. Roddam PL, Rollinson S, O'Driscoll M, Jeggo PA, Jack A and Morgan GJ: Genetic variants of NHEJ DNA ligase IV can affect the risk of developing multiple myeloma, a tumour characterised by aberrant class switch recombination. J Med Genet 39: 900-905, 2002.

100. Vangsted A, Gimsing P, Klausen TW, et al: Polymorphisms in the genes ERCC2, XRCC3 and CD3EAP influence treatment outcome in multiple myeloma patients undergoing autologous bone marrow transplantation. Int J Cancer 120: 1036-1045, 2007.

101. Hosgood HD III, Baris D, Zhang Y, et al: Caspase polymorphisms and genetic susceptibility to multiple myeloma. Hematol Oncol 26: 148-151, 2008

102. Ortega MM, Honma HN, Zambon L, et al: GSTM1 and codon 72 P53 polymorphism in multiple myeloma. Ann Hematol 86: 815-819, 2007.

103. Maggini V, Buda G, Galimberti S, et al: Lack of association of NQO1 and GSTP1 polymorphisms with multiple myeloma risk. Leuk Res 32: 988-990, 2008

104. Ortega MM, Nascimento H, Melo MB, Teori MT, Costa FF and Lima CS: Polymorphisms of glutathione S-transferase mu1 (GSTM1) and theta1 (GSTT1) genes in multiple myeloma. Acta Haematol 109: 108-109, 2003.

105. Lincz LF, Kerridge I, Scorgie FE, Bailey M, Enno A and Spencer A: Xenobiotic gene polymorphisms and susceptibility to multiple myeloma. Haematologica 89: 628-629, 2004.

106. Lincz LF, Scorgie FE, Robertson R and Enno A: Genetic variations in benzene metabolism and susceptibility to multiple myeloma. Leuk Res 31: 759-763, 2007.

107. Gold LS, De Roos AJ, Brown EE, et al: Associations of common variants in genes involved in metabolism and response to exogenous chemicals with risk of multiple myeloma. Cancer Epidemiol 33: 276-280, 2009.

108. Pereira TV, Rudnicki M, Pereira AC, Pombo-de-Oliveira MS and Franco RF: 5,10-Methylenetetrahydrofolate reductase polymorphisms and acute lymphoblastic leukemia risk: a metaanalysis. Cancer Epidemiol Biomarkers Prev 15: 1956-1963, 2006 .

109. Webb EL, Rudd MF, Sellick GS, et al: Search for low penetrance alleles for colorectal cancer through a scan of 1467 non-synonymous SNPs in 2575 cases and 2707 controls with validation by kin-cohort analysis of 14704 first-degree relatives. Hum Mol Genet 15: 3263-3271, 2006. 
110. Gonzalez Ordonez AJ, Fernandez Carreira JM, Fernandez Alvarez CR, et al: Normal frequencies of the C677T genotypes on the methylenetetrahydrofolate reductase (MTHFR) gene among lymphoproliferative disorders but not in multiple myeloma. Leuk Lymphoma 39: 607-612, 2000.

111. Yanamandra K, Bocchini JA Jr and Thurmon TF: Methylenetetrahydrofolate reductase $677 \mathrm{CC}$ normal genotype may protect against multiple myeloma. Br J Haematol 120: 1094-1095; author reply 1095-1096, 2003.

112. Lima CS, Ortega MM, Ozelo MC, et al: Polymorphisms of methylenetetrahydrofolate reductase (MTHFR), methionine synthase (MTR), methionine synthase reductase (MTRR), and thymidylate synthase (TYMS) in multiple myeloma risk. Leuk Res 32: 401-405, 2008.

113. Chiusolo P, Farina G, Putzulu R, et al: Analysis of MTHFR polymorphisms and P16 methylation and their correlation with clinical-biological features of multiple myeloma. Ann Hematol 85: 474-477, 2006.

114. Kim HN, Kim YK, Lee IK, et al: Polymorphisms involved in the folate metabolizing pathway and risk of multiple myeloma. Am J Hematol 82: 798-801, 2007.

115. Gonzalez-Fraile MI, Garcia-Sanz R, Mateos MV, et al: Methylenetetrahydrofolate reductase genotype does not play a role in multiple myeloma pathogenesis. Br J Haematol 117: 890-892, 2002.

116. Hatzimichael E, Dasoula A, Benetatos L, et al: Study of specific genetic and epigenetic variables in multiple myeloma. Leuk Lymphoma 51: 2270-2274, 2010.

117. Lincz LF, Scorgie FE, Kerridge I, Potts R, Spencer A and Enno A: Methionine synthase genetic polymorphism MS A2756G alters susceptibility to follicular but not diffuse large B-cell non-Hodgkin's lymphoma or multiple myeloma. Br J Haematol 120: 1051-1054, 2003.

118. Zintzaras E, Giannouli S, Rodopoulou P and Voulgarelis M: The role of MTHFR gene in multiple myeloma. J Hum Genet 53: 499-507, 2008.

119. Jamroziak K, Balcerczak E, Calka K, et al: Polymorphisms and haplotypes in the multidrug resistance 1 gene (MDR1/ABCB1) and risk of multiple myeloma. Leuk Res 33: 332-335, 2009.

120. Kang SH, Kim TY, Kim HY, et al: Protective role of CYP1A1*2A in the development of multiple myeloma. Acta Haematol 119: 60-64, 2008.

121. Neben K, Mytilineos J, Moehler TM, et al: Polymorphisms of the tumor necrosis factor- $\alpha$ gene promoter predict for outcome after thalidomide therapy in relapsed and refractory multiple myeloma. Blood 100: 2263-2265, 2002.

122. Dasgupta RK, Adamson PJ, Davies FE, et al: Polymorphic variation in GSTP1 modulates outcome following therapy for multiple myeloma. Blood 102: 2345-2350, 2003.

123. Dumontet $\mathrm{C}$, Landi S, Reiman T, et al: Genetic polymorphisms associated with outcome in multiple myeloma patients receiving high-dose melphalan. Bone Marrow Transplant 45: 1316-1324, 2010.

124. Maggini V, Buda G, Galimberti S, et al: Response to chemotherapy and tandem autologous transplantation of multiple myeloma patients and GSTP1 and TYMS polymorphisms. Leuk Res 32: 49-53, 2008.

125. Maggini V, Buda G, Galimberti S, et al: Association of folate transporter SLC19A1 polymorphisms with the outcome of multiple myeloma after chemotherapy and tandem autologous transplantation. Leukemia 21: 176-178, 2007.

126. Schilthuizen C, Broyl A, van der Holt B, De Knegt Y, Lokhorst H and Sonneveld P: Influence of genetic polymorphisms in CYP3A4, CYP3A5, GSTP1, GSTM1, GSTT1 and MDR1 genes on survival and therapy-related toxicity in multiple myeloma. Haematologica 92: 277-278, 2007.

127. Maggini V, Buda G, Martino A, et al: MDR1 diplotypes as prognostic markers in multiple myeloma. Pharmacogenet Genomics 18: 383-389, 2008.

128. Buda G, Ricci D, Huang CC, et al: Polymorphisms in the multiple drug resistance protein 1 and in P-glycoprotein 1 are associated with time to event outcomes in patients with advanced multiple myeloma treated with bortezomib and pegylated liposomal doxorubicin. Ann Hematol 89: 1133-1140, 2010.

129. Buda G, Martino A, Maggini V, et al: MDR1 C3435T polymorphism indicates a different outcome in advanced multiple myeloma. Acta Haematol 122: 42-45, 2009.
130. Buda G, Maggini V, Galimberti S, et al: MDR1 polymorphism influences the outcome of multiple myeloma patients. Br J Haematol 137: 454-456, 2007.

131. Vangsted AJ, Soeby K, Klausen TW, et al: No influence of the polymorphisms CYP2C19 and CYP2D6 on the efficacy of cyclophosphamide, thalidomide, and bortezomib in patients with Multiple Myeloma. BMC Cancer 10: 404, 2010.

132. Li Y, Hou J, Jiang H, et al: Polymorphisms of CYP2C19 gene are associated with the efficacy of thalidomide based regimens in multiple myeloma. Haematologica 92: 1246-1249, 2007.

133. Vangsted AJ, Klausen TW, Gimsing P, et al: A polymorphism in NFKBI is associated with improved effect of interferon- $\alpha$ maintenance treatment of patients with multiple myeloma after high-dose treatment with stem cell support. Haematologica 94: 1274-1281, 2009.

134. Vangsted AJ, Klausen TW, Abildgaard N, et al: Single nucleotide polymorphisms in the promoter region of the IL1B gene influence outcome in multiple myeloma patients treated with high-dose chemotherapy independently of relapse treatment with thalidomide and bortezomib. Ann Hematol 90: 1173-1181, 2011.

135. Bachmann HS, Novotny J, Sixt S, et al: The G-Allele of the PSMA6-8C $>$ G polymorphism is associated with poor outcome in multiple myeloma independently of circulating proteasome serum levels. Eur J Haematol 85: 108-113, 2010.

136. Richardson PG: Towards a better understanding of treatmentrelated peripheral neuropathy in multiple myeloma. Lancet Oncol 11: 1014-1016, 2010.

137. Mileshkin L, Stark R, Day B, Seymour JF, Zeldis JB and Prince HM: Development of neuropathy in patients with myeloma treated with thalidomide: patterns of occurrence and the role of electrophysiologic monitoring. J Clin Oncol 24: 4507-4514, 2006

138. Richardson PG, Weller E, Jagannath S, et al: Multicenter, phase I, dose-escalation trial of lenalidomide plus bortezomib for relapsed and relapsed/refractory multiple myeloma. J Clin Oncol 27: 5713-5719, 2009.

139. Broyl A, Corthals SL, Jongen JL, et al: Mechanisms of peripheral neuropathy associated with bortezomib and vincristine in patients with newly diagnosed multiple myeloma: a prospective analysis of data from the HOVON-65/GMMG-HD4 trial. Lancet Oncol 11: 1057-1065, 2010.

140. Johnson DC, Corthals SL, Walker BA, et al: Genetic factors underlying the risk of thalidomide-related neuropathy in patients with multiple myeloma. J Clin Oncol 29: 797-804, 2011.

141. Johnson DC, Corthals S, Ramos C, et al: Genetic associations with thalidomide mediated venous thrombotic events in myeloma identified using targeted genotyping. Blood 112: 4924-4934, 2008

142. Van den Wyngaert T, Huizing MT and Vermorken JB: Osteonecrosis of the jaw related to the use of bisphosphonates. Curr Opin Oncol 19: 315-322, 2007.

143. Sarasquete ME, Garcia-Sanz R, Marin L, et al: Bisphosphonaterelated osteonecrosis of the jaw is associated with polymorphisms of the cytochrome P450 CYP2C8 in multiple myeloma: a genome-wide single nucleotide polymorphism analysis. Blood 112: 2709-2712, 2008.

144. Song H, Ramus SJ, Tyrer J, et al: A genome-wide association study identifies a new ovarian cancer susceptibility locus on 9p22.2. Nat Genet 41: 996-1000, 2009.

145. Ahmed S, Thomas G, Ghoussaini M, et al: Newly discovered breast cancer susceptibility loci on $3 \mathrm{p} 24$ and $17 \mathrm{q} 23.2$. Nat Genet 41: 585-590, 2009.

146. Lindstrom S, Schumacher F, Siddiq A, et al: Characterizing associations and SNP-environment interactions for GWASidentified prostate cancer risk markers - results from BPC3. PLoS One 6: e17142, 2011.

147. Sherborne AL, Hemminki K, Kumar R, et al: Rationale for an international consortium to study inherited genetic susceptibility to childhood acute lymphoblastic leukemia. Haematologica 96: 1049-1054, 2011.

148. Tomlinson IP, Dunlop M, Campbell H, et al: COGENT (COlorectal cancer GENeTics): an international consortium to study the role of polymorphic variation on the risk of colorectal cancer. Br J Cancer 102: 447-454, 2009. 